\title{
KONTRIBUSI IMPLEMENTASI MANAJEMEN SEKOLAH BERBASIS NILAI-NILAI KEARIFAN LOKAL TRI HITA KARANA, KEPEMIMPINAN PELAYANAN KEPALA SEKOLAH, KEPUASAN KERJA, DAN KOMITMEN ORGANISASIONAL TERHADAP KINERJA GURU SMP DI KECAMATAN GEROKGAK
}

\author{
Luh Putu Sri Utami, Anak Agung Gede Agung, Dewa Gede Hendra Divayana \\ Program Studi Administrasi Pendidikan, Program Pascasarjana \\ Universitas Pendidikan Ganesha \\ Singaraja, Indonesia
}
e-mail: \{utami,.s.pd.@undiksha.ac.id, agungtps2056@gmail.com, hendra.divayana@undiksha.ac.id\}

\begin{abstract}
ABSTRAK
Penelitian ini dilatarbelakangi karena adanya penyimpangan-penyimpangan perilaku karena kurang siapnya warga sekolah menghadapi kemajuan teknologi di era globalisasi ini, dimana hal ini dipengaruhi oleh faktor eksternal dan faktor internal. Faktor eksternalnya adalah implementasi manajemen sekolah berbasis nilai-nilai kearifan lokal Tri Hita Karana dan kepemimpinan pelayan kepala sekolah.Faktor internalnya adalah kepuasan kerja dan komitmen organisasional.Penelitian ini bertujuan untuk mengetahui kontribusi implementasi manajemen sekolah berbasis nilai-nilai kearifan lokal Tri Hita Karana, kepemimpinan pelayanan kepala sekolah, kepuasan kerja, dan komitmen organisasional terhadap kinerja guru SMP di Kecamatan Gerokgak.Penelitian ini adalah penelitian "ex-post facto" dengan teknik analisis jalur (path analysis)dengan besar sampel 138 orang.Data dikumpulkan dengan kuesioner dan dokumen.Analisis data dilakukan dengan teknik regresi sederhana, regresi ganda, dan korelasi parsial. Hasil penelitian menunjukkan bahwa: 1) terdapat kontribusi secara langsung yang signifikan antara Implementasi Manajemen Sekolah Berbasis Nilai-nilai Kearifan Lokal Tri Hita Karana $\left(X_{1}\right)$ terhadap kepuasan kerja $\left(X_{3}\right)$ guru SMP di Kecamatan Gerokgak dengan koefisien korelasi sebesar 0,664 . 2) terdapat kontribusi secara langsung yang signifikan antara Implementasi Manajemen Sekolah Berbasis Nilai-nilai Kearifan Lokal Tri Hita Karana $\left(X_{1}\right)$ dengan komitmen organisasional $\left(X_{4}\right)$ guru SMP di Kecamatan Gerokgak dengan koefisien korelasi sebesar 0,523. 3) tidak terdapat kontribusi secara langsung yang signifikan antara Implementasi Manajemen Sekolah Berbasis Nilai-nilai Kearifan Lokal Tri Hita Karana $\left(X_{1}\right)$ melalui komitmen organisasional $\left(X_{4}\right)$ terhadap kinerja guru $(Y)$ guru SMP di Kecamatan Gerokgak. Nilai pengaruh langsung sebesar 0,492 dan pengaruh tidak langsung sebesar 0,126 yang berarti bahwa nilai pengaruh langsung lebih besar dibandingkan dengan nilai pengaruh tidak langsung, hasil ini menunjukkan bahwa secara tidak langsung $X_{1}$ melalui $X_{4}$ mempunyai pengaruh yang tidak signifikan terhadap $Y$. 4) terdapat kontribusi secara langsung yang signifikan antara implementasi manajemen sekolah berbasis nilai-nilai kearifan lokal Tri Hita Karana $\left(X_{1}\right)$ dengan kepemimpinan pelayanan kepala sekolah $\left(\mathrm{X}_{2}\right)$ guru SMP di Kecamatan Gerokgak dengan koefisien korelasi sebesar 0,347 . 5) terdapat kontribusi secara langsung yang signifikan antara kepemimpinan pelayanan kepala sekolah $\left(X_{2}\right)$ dengan kepuasan kerja $\left(X_{3}\right)$ guru SMP di Kecamatan Gerokgak dengan koefisien korelasi sebesar $0,495.6)$ terdapat kontribusi secara langsung yang signifikan antara kepemimpinan pelayanan kepala sekolah $\left(\mathrm{X}_{2}\right)$ dengan komitmen organisasional $\left(\mathrm{X}_{4}\right)$ guru SMP di Kecamatan Gerokgak dengan koefisien korelasi sebesar 0,463. 7) tidak terdapat kontribusi secara langsung yang signifikan antara kepemimpinan pelayanan kepala sekolah $\left(\mathrm{X}_{2}\right)$ melalui kepuasan kerja $\left(\mathrm{X}_{3}\right)$ terhadap kinerja guru $(\mathrm{Y})$ SMP di Kecamatan Gerokgak. Nilai pengaruh langsung sebesar 0,201 dan pengaruh tidak langsung sebesar 0,059 yang berarti bahwa nilai pengaruh langsung lebih besar dibandingkan dengan nilai pengaruh tidak langsung, hasil ini menunjukkan bahwa secara tidak langsung $X_{2}$ melalui $X_{3}$ mempunyai pengaruh yang tidak signifikan terhadap $Y$. 8) tidak terdapat kontribusi secara langsung yang signifikan antara kepemimpinan pelayanan kepala sekolah $\left(\mathrm{X}_{2}\right)$ melalui komitmen organisasional $\left(\mathrm{X}_{4}\right)$ terhadap kinerja guru (Y) SMP di Kecamatan Gerokgak. Nilai pengaruh langsung sebesar 0,201 dan pengaruh tidak langsung sebesar 0,066 yang berarti bahwa nilai pengaruh langsung lebih besar dibandingkan dengan nilai pengaruh tidak langsung, hasil ini menunjukkan bahwa secara tidak langsung $X_{2}$ melalui $X_{4}$ mempunyai pengaruh yang tidak signifikan terhadap Y. 9) tidak terdapat kontribusi secara langsung yang
\end{abstract}


signifikan antara Implementasi Manajemen Sekolah Berbasis Nilai-nilai Kearifan Lokal Tri Hita Karana $\left(\mathrm{X}_{1}\right)$ melalui kepuasan kerja $\left(\mathrm{X}_{3}\right)$ terhadap kinerja guru $(\mathrm{Y})$ SMP di Kecamatan Gerokgak. Nilai pengaruh langsung sebesar 0,492 dan pengaruh tidak langsung sebesar 0,125 yang berarti bahwa nilai pengaruh langsung lebih besar dibandingkan dengan nilai pengaruh tidak langsung, hasil ini menunjukkan bahwa secara tidak langsung $X_{1}$ melalui $X_{3}$ mempunyai pengaruh yang tidak signifikan terhadap $Y$. 10) terdapat kontribusi secara langsung yang signifikan antara kepuasan kerja $\left(\mathrm{X}_{3}\right)$ terhadap kinerja guru $(\mathrm{Y})$ SMP di Kecamatan Gerokgak dengan koefisien korelasi sebesar 0,783. 11) terdapat kontribusi secara langsung yang signifikan antara kepemimpinan pelayanan kepala sekolah $\left(\mathrm{X}_{2}\right)$ terhadap kinerja guru $(\mathrm{Y})$ SMP di Kecamatan Gerokgak dengan koefisien korelasi sebesar 0,579. 12) terdapat kontribusi secara langsung yang signifikan antara implementasi manajemen sekolah berbasis nilai-nilai kearifan lokal Tri Hita Karana $\left(\mathrm{X}_{1}\right)$ terhadap kinerja guru (Y) SMP di Kecamatan Gerokgak dengan koefisien korelasi sebesar 0,821. 13) secara bersama-sama, ada kontribusi yang signifikan antara manajemen sekolah berbasis nilai-nilai kearifan lokal Tri Hita Karana, kepemimpinan pelayanan kepala sekolah, kepuasan kerja, dan komitmen organisasional terhadap kinerja guru SMP di Kecamatan Gerokgak dengan koefisien korelasi ganda sebesar 0,917 dan kontribusinya sebesar 84,1\% terhadap kinerja guru SMP di Kecamatan Gerokgak.

Kata kunci: manajemen sekolah berbasis nilai-nilai kearifan lokal Tri Hita Karana, kepemimpinan, kepuasan kerja, komitmen organisasional, kinerja guru

\section{ABSTRACT}

This research is motivated because of the deviation of behavior because of the lack of readyness of the citizens of the school facing technological progress in this globalization era, where this is influenced by external factors and internal factors. The external factors is the implementation of school management based on local wisdom values of Tri Hita Karana and principal servant leadership,internal factors are job satisfaction and organizational commitment. This study aims to determine the contribution of school management implementation based on local wisdom values of Tri Hita Karana, leadership of headmaster services, job satisfaction, and organizational commitment to the performance of junior high school teachers in Gerokgak sub-district. This research is an "ex-post facto" research with path analysis technique with 138 sample. Data were collected with questionnaires and documents. Data analysis was performed by simple regression, multiple regression, and partial correlation. The result of the research shows that: 1) there is a significant direct contribution between Implementation of School Based Management of Local Wisdom Tri Hita Karana (X1) to job satisfaction (X3) of junior high school teacher in Gerokgak sub district with correlation coefficient 0,664.2) there is a significant direct contribution between Implementation of School Based Management of Local Wisdom Values Tri Hita Karana (X1) with organizational commitment (X4) of junior high school teachers in Gerokgak District with correlation coefficient of 0,523. 3) there is no significant direct contribution between Implementation of School Based Management of Local Wisdom Tri Hita Karana (X1) through organizational commitment (X4) to teacher performance $(Y)$ of junior high school teachers in Gerokgak sub-district. The direct influence value of 0.492 and the indirect effect of 0.126 which means that the value of direct influence is greater than the value of indirect influence, this result indicates that indirectly X1 through X4 has an insignificant influence on $Y$. 4) there is a direct contribution which is significant between the implementation of school management based on local wisdom values Tri Hita Karana (X1) with the leadership of school principal service (X2) of junior high school teachers in Gerokgak District with a correlation coefficient of 0.347. 5) there is a significant direct contribution between headmaster service leadership (X2) and job satisfaction (X3) of junior high school teachers in Gerokgak sub district with correlation coefficient of 0.495. 6) there is a significant direct contribution between headmaster service leadership (X2) and organizational commitment (X4) of junior high school teachers in Gerokgak sub district with correlation coefficient of 0.463. 7) there is no significant direct contribution between headmaster service leadership (X2) through job satisfaction (X3) on teacher performance $(\mathrm{Y})$ of junior high school in Gerokgak sub-district. The value of direct influence of 0.201 and the indirect effect of 0.059 which means that the value of direct influence is greater than the value of indirect influence, this result indicates that indirectly $X 2$ through $X 3$ has an insignificant influence on $Y .8$ ) there is no contribution (X2) through organizational commitment (X4) to teacher performance $(Y)$ of junior high school in Gerokgak sub-district. The value of direct influence is 0.201 and the indirect effect is 0.066 which means that the value of direct influence is greater than the value of indirect influence, this result indicates that indirectly X2 through X4 has an insignificant effect on $Y .9)$ there is no contribution directly between the Implementation of School Based Management of Local Wisdom Values Tri Hita Karana (X1) through job satisfaction (X3) on the performance of teachers (Y) 
SMP in the District Gerokgak. The value of direct influence of 0.492 and the indirect effect of 0.125 which means that the value of direct influence is greater than the value of indirect influence, this result indicates that indirectly $\mathrm{X} 1$ through $\mathrm{X} 3$ has an insignificant influence on $\mathrm{Y} .10$ ) there is a direct contribution which is significant between job satisfaction (X3) on teacher performance (Y) SMP in District Gerokgak with correlation coefficient of 0.783 . 11) there is a significant direct contribution between headmaster service leadership (X2) on teacher performance (Y) SMP in Gerokgak District with correlation coefficient of 0,579. 12) there is a significant direct contribution between the implementation of school management based on local wisdom values Tri Hita Karana (X1) on teacher performance (Y) SMP in Gerokgak District with correlation coefficient of 0.821 . 13) collectively, there is a significant contribution between school management based on local wisdom values Tri Hita Karana, headmaster service leadership, job satisfaction, and organizational commitment to the performance of junior high school teachers in Gerokgak District with a double correlation coefficient of 0.917 and their contribution amounting to $84.1 \%$ of the performance of junior high school teachers in the district of Gerokgak..

Keywords: school management based on local wisdom values Tri Hita Karana, leadership, job satisfaction, organizational commitment, teacher performance

\section{PENDAHULUAN}

Permasalahan yang ada dewasa ini di lingkungan sekolah terutama sekolah menengah pertama di kecamatan Gerokgak adalah dengan adanya kemajuan teknologi sering terjadi penyimpangan-penyimpangan perilaku karena kurang siapnya warga sekolah terutama murid menghadapi kemajuan teknologi di era globalisasi ini.Berbagai aplikasi yang ada di media sosial memudahkan mereka untuk mengakses informasi dari internet baik informasi yang bersifat positif maupun negatif. Maraknya berbagai aplikasi yang terdapat di media sosial juga seringkali menyebabkan kurangnya komunikasi antar warga sekolah baik antar guru dengan siswa maupun siswa dengan siswa. Anak-anak SMP khususnya SMP di kecamatan Gerokgak belum siap dengan kemajuan teknologi tersebut, ini terbukti dengan adanya perkelahian antar sekolah yang berawal dari pertengkaran di media sosial, adanya pernikahan di usia dini, dan yang lainnya. Sehingga perlu kiranya dewasa ini di sekolah-sekolah khususnya sekolah menengah pertama menerapkan pendidikan yang berbasis nilai-nilai kearifan lokal Tri Hita Karana untuk memperbaiki sikap dan mental di kalangan siswa menengah pertama agar benar-benar siap menghadapi kemajuan teknologi di era globalisasi ini. Hal ini bisa dimulai dari pendidikan THK terhadap guru sebagai tenaga pendidik.

Kinerja guru adalah hasil kerja yang dapat dicapai oleh seorang guru di lembaga pendidikan atau madrasah sesuai dengan tugas dan tanggung jawab dalam mencapai tujuan pendidikan (Asf \& Mustofa, 2013:155-156).Keberhasilan seorang guru harus memenuhi kriteria yang telah ditetapkan, apabila guru telah memenuhi kriteria tersebut berarti seorang guru dapat dikatakan berhasil dan memiliki kualitas yang baik.Sebaliknya apabila seorang guru belum memenuhi kriteria yang baik maka guru belum dapat dikatakan berhasil.

Komitmen guru dalam memberikan pengetahuan, tenaga serta pikiran kepada siswa adalah hal yang sangat penting guna mencapai tujuan pendidikan.Sebagai sumber daya sekolah, guru dituntut memiliki komitmen yang tinggi agar dapat menjalankan fungsinya sebagai pengajar yang berdedikasi. Komitmen merupakan tindakan seseorang yang berusaha sangat keras untuk melakukan kewajiban pada seseorang atau mendukung sesuatu dimasa depan.

Pendidikan Tri Hita Karanaadalah pendidikan yang bertujuan menghasilkan luaran berkarakter dan berbudaya Tri Hita Karana. Pengembangan pendidikan Tri Hita Karana membutuhkan pembudayaan nilai-nilai luhur Tri Hita Karanasebagai basis pengembangan standar kompetensi lulusan, standar isi program, standar proses pembelajaran, standar penilaian, standar pendidik dan tenaga kependidikan, standar sarana-prasarana, standar pengeloalaan, dan standar biaya.

Selain faktor kompetensi dan komitmen organisasional untuk meningkatkan kepuasan kerja guru, ada pula faktor lain yang mempengaruhi kepuasan kerja guru yaitu manajemen sekolah, pelayanan kepala sekolah sehingga meningkatkan kinerja guru. Manajemen sekolah jauh lebih penting daripada keterampilan-keterampilan terkait atau teknik komunikasi semata- 
mata dalam menciptakan suatu organisasi yang efektif.Selain itu, manajemen sekolah yang kondusif merupakan prasyarat terselenggaranya proses pembelajaran yang efektif (Rohiat, 2010:34).

Peran utama kepemimpinan kepala sekolah adalah sebagai: edukator, manager, administrator, supervisor, leader, innovator, dan motivator (Depdiknas, 2006:21). Kepemimpinan kepala sekolah yang baik yang sesuai dengan standar yang telah ditentukan akan menghasilkan pendidikan yang bermutu dan berkualitas baik. Kepemimpinan kepala sekolah berpengaruh positif dalam kemajuan keprofesionalan seorang guru (Yuliana, 2014:46)

Untuk hal itulah, kontribusi implementasi manajemen sekolah berbasis nilai-nilai kearifan lokal Tri Hita Karana, kepemimpinan pelayanan kepala sekolah, kepuasan kerja, dan komitmen organisasional terhadap kinerja guru SMP di Kecamatan Gerokgak menjadi hal yang sangat menarik untuk dikaji dan diteliti.

\section{METODE PENELITIAN}

Desain atau rancangan penelitian ini tergolong penelitian deskriptif dan korelasional.Dikatakan deskriptif, karena peneliti berusaha memperoleh informasi yang berkenaan dengan fenomena yang diamati saat ini selanjutnya mendeskripsikan data tentang objek atau variabel yang diteliti (Suharsimi, 1989: 43).Dalam penelitian berusaha untuk mendeskripsikan data tentang objek atau variabel penelitian yang ada pada Sekolah Menengah Pertama Negeri di Kecamatan Gerokgak.

Disebut korelasional, karena peneliti ingin menjelaskan hubungan atau korelasi antara berbagai variabel berdasarkan besar kecilnya koefisien korelasi (Ardhana, 1987: 33).Dalam kaitan ini, Fraenkel dan Wallen (1993:286) mengungkapkan "correlational research attempts to investigate possible relationships among variabels without trying to influence those variables". Dalam penelitian ini, yang dicari hubungan antara variabel-variabel: implementasi manajemen sekolah berbasis nilai-nilai kearifan lokal Tri Hita Karana $\left(\mathrm{X}_{1}\right)$, kepemimpinan pelayanan kepala sekolah $\left(\mathrm{X}_{2}\right)$, kepuasan kerja $\left(\mathrm{X}_{3}\right)$, komitmen organisasional $\left(\mathrm{X}_{4}\right)$ dengan kinerja guru $(\mathrm{Y})$.

Penelitian ini melibatkan dua variabel bebas atau prediktor, yaitu implementasi manajemen sekolah berbasis nilai-nilai kearifan lokal Tri Hita Karana dan kepemimpinan pelayanan kepala sekolah, lalu melibatkan dua variabel dua variabel mediator yakni kepuasan kerja dan komitmen organisasonal, dan melibatkan satu variabel terikat yakni kinerja guru.

Sesuai dengan model hubungan di atas, maka untuk analisis data dalam penelitian ini digunakan teknik analisis jalur (path analysis). Dalam analisis jalur, variabel bebas terbagi dalam sejumlah blok yang tersusun secara hirarkhis. Apabila dalam suatu penelitian tidak ada hubungan antara variabel bebas yang satu dengan variabel bebas yang lainnya, dan masingmasing variabel bebas hanya mempunyai hu-bungan langsung dengan variabel terikat, digunakan teknik analisis regresi sebagai analisis data.Sebaliknya, jika di antara variabel bebas yang satu terdapat hubungan dengan variabel bebas lainnya, dan mempunyai hubungan langsung ataupun tidak langsung dengan variabel terikat, maka digunakan analisis jalur.

Agung $(2014 ; 69)$ menyatakan populasi adalah keseluruhan objek dalam suatu penelitian. Hal senada juga diungkapkan oleh Sugiyono (2016:61) yang menyatakan populasi adalah wilayah generalisasi yang terdiri atas objek dan subjek yang mempunyai kualitas dan karakteristik tertentu yang ditetapkan oleh peneliti untuk dipelajari dan kemudian ditarik kesimpulannya. Populasi dalam penelitian ini adalah seluruh guru PNS pada sekolah Menengah Pertama Negeri di Kecamatan Gerokgak tahun 2017 yang berjumlah 138 orang guru.

Sugiyono (2016: 120) menyatakan bahwa sampel adalah bagian dari jumlah dan karakteristik yang dimiliki populasi tersebut.Sedangkan Agung (2016: 8) menyatakan bahwa sampel merupakan bagian dari populasi yang secara langsung dikenai penelitian.Dikarenakan jumlah populasi yang tidak terlalu banyak, sehingga dalam penelitian ini menggunakan seluruh populasi menjadi sampel penelitian.Maka dari itu, sampel dalam penelitian ini berjumlah 138 orang guru. 
Penelitian ini melibatkan tiga variabel, yaitu variabel bebas (independent variable), variabel terikat (dependent variable), dan variabel moderator.Variabel bebasnya terdiri dari implementasi manajemen sekolah berbasis nilai-nilai kearifan lokal Tri Hita Karana dan kepemimpinan pelayanan kepala sekolah.Variabel terikatnya yakni kinerja guru. Variabel moderatornya, yaitu kepuasan kerja dan komitmen organisasional

Alat pengumpul data harus memenuhi persyaratan yaitu syarat validitas dan reliabilitas dalam mengungkap apa yang hendak diukur. Ada dua persyaratan yang hendak digunakan dalam pengumpulan data penelitian yaitu validitas dan reliabilitas (Hamzah, 2007:63).Validitas instrumen dalam penelitian ini meliputi dua segi yaitu validitas isi dan validitas butir.Validitas isi dibantu oleh dua orang ahli/ expert, kemudian dianalisis dengan teknik Gregory.

Sebelum instrumen digunakan, maka perlu diuji dahulu validitas dari masing-masing pertanyaan yang ada sebagai alat pengambilan data.Dengan demikian terlebih dahulu diadakan uji coba terhadap kuisioner kemudian hasil uji coba ini dianalisis.Untuk menguji validitas butir rumus yang digunakan adalah rumus kontribusi product moment dari Pearson (Arikunto, 1995).

Pengujian terhadap reabilitas instrumen dilakukan melalui pendekatan ketetapan internal. Uji reliabilitas adalah ketepatan dan keajegan alat pengukur tersebut dalam menilai apa yang diinginkan, artinya kapanpun alat tersebut digunakan akan diperoleh hasil yang sama (Puger, 2004). Pengujian reliabilitas dengan rumus Alpha dari Crombach (Arikunto, 1997:164).

Kegiatan analisis data terdiri atas kegiatan pengolahan data dan analisis statistik. Kegiatan analisis data meliputi: 1) menyunting data secara manual. Penyuntingan dilakukan karena kemungkinan ada data yang tidak jelas, atau kesalahan dalam pengisian instrument, sehingga tidak memenuhi syarat untuk dianalisis, 2) mentabulasi data, dan 3) mengolah data dalam bentuk sesuai kebutuhan.

Untuk menguji hipotesis yang telah dirumuskan, terlebih dahulu dilakukan analisis data yang telah dikumpulkan. Dalam melakukan analisis data untuk penelitian ini dilakukan dengan tiga tahapan yakni: 1) tahap deskripsi data, 2) tahap pengujian persyarat analisis, 3) tahap pengujian hipotesis.

Data yang telah diperoleh dari penelitian dideskripsikan menurut masing-masing variabel. Oleh tujuannya seperti itu, maka akan dicari harga rerata (M), standar deviasi (SD), modus (Mo), dan median (Me) setiap variabel yang diteliti.

Setelah data dideskripsikan, maka analisis dilanjutkan dengan menggunakan teknik regresi sederhana, regresi ganda, dan korelasi varsial.Persyaratan yang berkaitan dengan teknik analisis data tersebut harus dibuktikan secara statistik.

Setelah seluruh uji prasyarat terpenuhi, maka dilanjutkan dengan uji hipotesis. Untuk mendeskripsikan data tentang implementasi manajemen sekolah berbasis nilai-nilai kearifan lokal Tri Hita Karana (X1), kepemimpinan pelayanan kepala sekolah (X2), kepuasan kerja (X3), komitmen organisasional (X4), dan kinerja guru (Y), digunakan norma absolut dengan skala lima, dan untuk menguji hubungan antara variabel bebas serta variabel moderator dan variabel terikat digunakan teknik analisis jalur (path analysis). Untuk menganalisis uji hipotesis dalam penelitian ini digunakan program SPSS-17.00 for windows.

\section{HASIL PENELITIAN DAN PEMBAHASAN}

Pertama, berdasarkan analisis data yang telah dilakukan, Secara normatif ditemukan bahwa terdapat kontribusi secara langsung yang signifikan antara implementasi manajemen sekolah berbasis nilai-nilai kearifan lokal Tri Hita Karana $\left(X_{1}\right)$ terhadap kepuasan kerja $\left(X_{3}\right)$ guru SMP di Kecamatan Gerokgak melalui persamaan garis regresi $\hat{y}=128,819+0,585 X_{1}$ dengan Freg $=106,971$ dengan kontribusi sebesar 44\%adalah signifikan dan linier. Karena Freg $>$ Ftabel. Berdasarkan analisis dengan komputer korelasi antara manajemen sekolah berbasis nilai-nilai kearifan lokal Tri Hita Karana $\left(X_{1}\right)$ dengan kepuasan kerja $\left(X_{3}\right)$ guru SMP di Kecamatan Gerokgak diperoleh $r_{\text {hitung }}=0,664$. Ini berarti $r_{\text {hitung }}=0,664$ signifikan pada $\alpha=0,05$ $\left(r_{\text {tabel }}=0,254\right)$. Temuan ini mengindikasikan bahwa terdapat kontribusi secara langsung yang signifikan antaraimplementasi manajemen sekolah berbasis nilai-nilai kearifan lokal Tri Hita Karana $\left(\mathrm{X}_{1}\right)$ terhadap kepuasan kerja $\left(\mathrm{X}_{3}\right)$ guru SMP di Kecamatan Gerokgak. 
Kedua, berdasarkan analisis data yang telah dilakukan, secara normatif ditemukan bahwa terdapat kontribusi secara langsung yang signifikan antara implementasi manajemen sekolah berbasis nilai-nilai kearifan lokal Tri Hita Karana $\left(\mathrm{X}_{1}\right)$ dengan komitmen organisasional $\left(\mathrm{X}_{4}\right)$ guru SMP di Kecamatan Gerokgak.melalui persamaan garis regresi $\hat{y}=20,104+0,746 . X_{1}$ dengan Freg $=51,094$ dengan kontribusi sebesar 27,3\% adalah signifikan dan linier. Berdasarkan analisis dengan komputer, korelasi antara manajemen sekolah berbasis nilai-nilai kearifan lokal Tri Hita Karana $\left(\mathrm{X}_{1}\right)$ dengan komitmen organisasional $\left(\mathrm{X}_{4}\right)$ diperoleh $\mathrm{r}_{\text {hitung }}=$ 0,523 . Ini berarti $r_{\text {hitung }}=0,523$ signifikan pada $\alpha=0,05\left(r_{\text {tabel }}=0,254\right)$. Temuan ini mengindikasikan bahwa terdapat kontribusi secara langsung yang signifikan antara Implementasi Manajemen Sekolah Berbasis Nilai-nilai Kearifan Lokal Tri Hita Karana ( $\left.\mathrm{X}_{1}\right)$ dengan komitmen organisasional $\left(\mathrm{X}_{4}\right)$ guru SMP di Kecamatan Gerokgak.

Ketiga, berdasarkan analisis data yang telah dilakukan, secara normatif ditemukan bahwa tidak terdapat kontribusi secara langsung yang signifikan antara implementasi manajemen sekolah berbasis nilai-nilai kearifan lokal Tri Hita Karana $\left(X_{1}\right)$ melalui komitmen organisasional $\left(\mathrm{X}_{4}\right)$ terhadap kinerja guru SMP $(\mathrm{Y})$ di Kecamatan Gerokgak. Berdasarkan hasil analisis diketahui pengaruh langsung antara $X_{1}$ terhadap $Y$ sebesar 0,492 . Sedangkan pengaruh tidak langsung $\mathrm{X}_{1}$ melalui $\mathrm{X}_{4}$ terhadap $\mathrm{Y}$ adalah perkalian antara nilai beta $\mathrm{X} 1$ terhadap $\mathrm{X}_{4}$ dengan nilai $X_{4}$ terhadap $Y$ yaitu: $0,630 \times 0,200=0,126$. Maka pengaruh langsung yang diberikan $X_{1}$ terhadap $Y$ adalah pengaruh langsung ditambah dengan pengaruh tidak langsung yaitu: 0,492 $+0,126=0,618$. Berdasarkan hasil perhitungan di atas diketahui bahwa nilai pengaruh langsung sebesar 0,492 dan pengaruh tidak langsung sebesar 0,126 yang berarti bahwa nilai pengaruh langsung lebih besar dibandingkan dengan nilai pengaruh tidak langsung, hasil ini menunjukkan bahwa secara tidak langsung $X_{1}$ melalui $X_{4}$ mempunyai pengaruh yang tidak signifikan terhadap Y.

Dengan demikian hipotesis nol $\left(\mathrm{H}_{0}\right)$ yang menyatakan "tidak terdapat kontribusi secara langsung yang signifikan antara implementasi manajemen sekolah berbasis nilai-nilai kearifan lokal Tri Hita Karana $\left(\mathrm{X}_{1}\right)$ melalui komitmen organisasional $\left(\mathrm{X}_{4}\right)$ terhadap kinerja guru SMP $(\mathrm{Y})$ di Kecamatan Gerokgak" diterima.

Keempat, berdasarkan analisis data yang telah dilakukan, secara normatif ditemukan bahwa terdapat kontribusi secara langsung yang signifikan antara implementasi manajemen sekolah berbasis nilai-nilai kearifan lokal Tri Hita Karana $\left(X_{1}\right)$ dengan kepemimpinan pelayanan kepala sekolah $\left(X_{2}\right)$ di Kecamatan Gerokgak dengan model regresi $\hat{y}=56,045+0,518 . X_{1}$ dengan Freg $=18,582$ dengan kontribusi sebesar $12 \%$ adalah signifikan dan linier. Hal itu dikarenakan Freg > Ftabel. Berdasarkan analisis dengan komputer, korelasi antara manajemen sekolah berbasis nilai-nilai kearifan lokal Tri Hita Karana $\left(X_{1}\right)$ dengan kepemimpinan pelayanan kepala sekolah $\left(X_{2}\right)$ di Kecamatan Gerokgak diperoleh $r_{\text {hitung }}=0,347$. Ini berarti $r_{\text {hitung }}=0,347$ signifikan pada $\alpha=0,05\left(r_{\text {tabel }}=0,254\right)$.

Ini berarti terdapat kontribusi secara langsung yang signifikan antara implementasi manajemen sekolah berbasis nilai-nilai kearifan lokal Tri Hita Karana $\left(\mathrm{X}_{1}\right)$ dengan kepemimpinan pelayanan kepala sekolah $\left(\mathrm{X}_{2}\right)$ di Kecamatan Gerokgak.

Kelima, berdasarkan analisis data yang telah dilakukan, secara normatif ditemukan bahwa terdapat kontribusi secara langsung yang signifikan antara kepemimpinan pelayanan kepala sekolah $\left(\mathrm{X}_{2}\right)$ dengan kepuasan kerja $\left(\mathrm{X}_{3}\right)$ guru SMP di Kecamatan Gerokgak dengan model regresi $\hat{y}=170,222+0,292 . X_{2}$. dengan Freg $=44,037$ dengan kontribusi sebesar $24,5 \%$ adalah signifikan dan linier. Hal itu dikarenakan Freg > Ftabel. Berdasarkan analisis dengan komputer, korelasi antara kepemimpinan pelayanan kepala sekolah $\left(\mathrm{X}_{2}\right)$ dengan kepuasan kerja $\left(X_{3}\right)$ di Kecamatan Gerokgak diperoleh $r_{\text {hitung }}=0,495$. Ini berarti $r_{\text {hitung }}=0,495$ signifikan pada $\alpha=0,05\left(r_{\text {tabel }}=0,254\right)$.

Ini berarti terdapat terdapat kontribusi secara langsung yang signifikan antara kepemimpinan pelayanan kepala sekolah $\left(\mathrm{X}_{2}\right)$ dengan kepuasan kerja $\left(\mathrm{X}_{3}\right)$ guru SMP di Kecamatan Gerokgak.

Keenam, berdasarkan analisis data yang telah dilakukan, secara normatif ditemukan bahwa terdapat kontribusi secara langsung yang signifikan antara kepemimpinan pelayanan kepala sekolah $\left(\mathrm{X}_{2}\right)$ dengan komitmen organisasional $\left(\mathrm{X}_{4}\right)$ guru SMP di Kecamatan Gerokgak 
dengan model regresi $\hat{y}=64,074+0,443 . X_{2}$. dengan Freg $=37,164$ dengan kontribusi sebesar $21,5 \%$ adalah signifikan dan linier. Hal itu dikarenakan Freg > Ftabel. Berdasarkan analisis dengan komputer, korelasi antara kepemimpinan pelayanan kepala sekolah $\left(\mathrm{X}_{2}\right)$ dengan komitmen organisasional $\left(\mathrm{X}_{4}\right)$ di Kecamatan Gerokgak diperoleh $r_{\text {hitung }}=0,463$. Ini berarti $r_{\text {hitung }}$ $=0,463$ signifikan pada $\alpha=0,05\left(r_{\text {tabel }}=0,254\right)$.

Ini berarti terdapat kontribusi secara langsung yang signifikan antara kepemimpinan pelayanan kepala sekolah $\left(\mathrm{X}_{2}\right)$ dengan komitmen organisasional $\left(\mathrm{X}_{4}\right)$ guru SMP di Kecamatan Gerokgak.

Ketujuh, berdasarkan analisis data yang telah dilakukan, secara normatif ditemukan bahwa tidak terdapat kontribusi secara langsung yang signifikan antara kepemimpinan pelayanan kepala sekolah $\left(\mathrm{X}_{2}\right)$ melalui kepuasan kerja $\left(\mathrm{X}_{3}\right)$ terhadap kinerja guru SMP $(\mathrm{Y})$ di Kecamatan Gerokgak. Berdasarkan hasil analisis diketahui pengaruh langsung antara $X_{2}$ terhadap $Y$ sebesar 0,201 . Sedangkan pengaruh tidak langsung $X_{2}$ melalui $X_{3}$ terhadap $Y$ adalah perkalian antara nilai beta $X_{2}$ terhadap $X_{3}$ dengan nilai $X_{3}$ terhadap $Y$ yaitu: $0,254 \times$ $0,233=0,059$. Maka pengaruh langsung yang diberikan $X_{2}$ terhadap $Y$ adalah pengaruh langsung ditambah dengan pengaruh tidak langsung yaitu: 0,201 $+0,059=0,260$. Berdasarkan hasil perhitungan di atas diketahui bahwa nilai pengaruh langsung sebesar 0,201 dan pengaruh tidak langsung sebesar 0,059 yang berarti bahwa nilai pengaruh langsung lebih besar dibandingkan dengan nilai pengaruh tidak langsung, hasil ini menunjukkan bahwa secara tidak langsung $X_{2}$ melalui $X_{3}$ mempunyai pengaruh yang tidak signifikan terhadap $Y$.

Dengan demikian hipotesis nol $\left(\mathrm{H}_{0}\right)$ yang menyatakan "tidak terdapat kontribusi secara langsung yang signifikan antara kepemimpinan pelayanan kepala sekolah $\left(\mathrm{X}_{2}\right)$ melalui kepuasan kerja $\left(\mathrm{X}_{3}\right)$ terhadap kinerja guru SMP $(\mathrm{Y})$ di Kecamatan Gerokgak" diterima.

Kedelapan, berdasarkan analisis data yang telah dilakukan, secara normatif ditemukan bahwa tidak terdapat kontribusi secara langsung yang signifikan antara kepemimpinan pelayanan kepala sekolah $\left(\mathrm{X}_{2}\right)$ melalui komitmen organisasional $\left(\mathrm{X}_{4}\right)$ terhadap kinerja guru SMP $(Y)$ di Kecamatan Gerokgak. Berdasarkan hasil analisis diketahui pengaruh langsung antara $X_{2}$ terhadap $Y$ sebesar 0,201 . Sedangkan pengaruh tidak langsung $X_{2}$ melalui $X_{4}$ terhadap $Y$ adalah perkalian antara nilai beta $X_{2}$ terhadap $X_{4}$ dengan nilai $X_{4}$ terhadap $Y$ yaitu: $0,328 x$ $0,200=0,066$. Maka pengaruh langsung yang diberikan $X_{2}$ terhadap $Y$ adalah pengaruh langsung ditambah dengan pengaruh tidak langsung yaitu: 0,201 $+0,066=0,267$. Berdasarkan hasil perhitungan di atas diketahui bahwa nilai pengaruh langsung sebesar 0,201 dan pengaruh tidak langsung sebesar 0,066 yang berarti bahwa nilai pengaruh langsung lebih besar dibandingkan dengan nilai pengaruh tidak langsung, hasil ini menunjukkan bahwa secara tidak langsung $\mathrm{X}_{2}$ melalui $\mathrm{X}_{4}$ mempunyai pengaruh yang tidak signifikan terhadap $\mathrm{Y}$.

Dengan demikian hipotesis nol $\left(\mathrm{H}_{0}\right)$ yang menyatakan "tidak terdapat kontribusi secara langsung yang signifikan antara kepemimpinan pelayanan kepala sekolah $\left(\mathrm{X}_{2}\right)$ melalui komitmen organisasional $\left(\mathrm{X}_{4}\right)$ terhadap kinerja guru SMP $(\mathrm{Y})$ di Kecamatan Gerokgak" diterima.

Kesembilan, berdasarkan analisis data yang telah dilakukan, secara normatif ditemukan bahwa tidak terdapat kontribusi secara langsung yang signifikan antara implementasi manajemen sekolah berbasis nilai-nilai kearifan lokal Tri Hita Karana $\left(\mathrm{X}_{1}\right)$ melalui kepuasan kerja $\left(\mathrm{X}_{3}\right)$ terhadap kinerja guru SMP $(\mathrm{Y})$ di Kecamatan Gerokgak. Berdasarkan hasil analisis diketahui pengaruh langsung antara $X_{1}$ terhadap $Y$ sebesar 0,492 . Sedangkan pengaruh tidak langsung $X_{1}$ melalui $X_{3}$ terhadap $Y$ adalah perkalian antara nilai beta $X_{1}$ terhadap $X_{3}$ dengan nilai $X_{3}$ terhadap $Y$ yaitu: $0,538 \times 0,233=0,125$. Maka pengaruh langsung yang diberikan $X_{1}$ terhadap $Y$ adalah pengaruh langsung ditambah dengan pengaruh tidak langsung yaitu: 0,492 $+0,125=0,617$. Berdasarkan hasil perhitungan di atas diketahui bahwa nilai pengaruh langsung sebesar 0,492 dan pengaruh tidak langsung sebesar 0,125 yang berarti bahwa nilai pengaruh langsung lebih besar dibandingkan dengan nilai pengaruh tidak langsung, hasil ini menunjukkan bahwa secara tidak langsung $X_{1}$ melalui $X_{3}$ mempunyai pengaruh yang tidak signifikan terhadap Y.

Dengan demikian hipotesis nol $\left(\mathrm{H}_{0}\right)$ yang menyatakan "tidak terdapat kontribusi secara langsung yang signifikan antara manajemen sekolah berbasis nilai-nilai kearifan lokal Tri Hita 
Karana $\left(\mathrm{X}_{1}\right)$ melalui kepuasan kerja $\left(\mathrm{X}_{3}\right)$ terhadap kinerja guru SMP $(\mathrm{Y})$ di Kecamatan Gerokgak" diterima.

Kesepuluh, berdasarkan analisis data yang telah dilakukan, Secara normatif ditemukan bahwa terdapat kontribusi secara langsung yang signifikan antara kepuasan kerja $\left(X_{3}\right)$ terhadap kinerja guru SMP (Y) di Kecamatan Gerokgak melalui persamaan garis regresi $\hat{y}=130,321+$ $1,648 \mathrm{X}_{3}$ dengan Freg $=215,047$ dengan kontribusi sebesar 61,3\%adalah signifikan dan linier. Karena Freg $>$ Ftabel. Berdasarkan analisis dengan komputer korelasi antara kepuasan kerja $\left(\mathrm{X}_{3}\right)$ dengan kinerja guru SMP $(\mathrm{Y})$ di Kecamatan Gerokgak diperoleh $\mathrm{r}_{\text {hitung }}=0,783$. Ini berarti $r_{\text {hitung }}=0,783$ signifikan pada $\alpha=0,05\left(r_{\text {tabel }}=0,254\right)$. Temuan ini mengindikasikan bahwa terdapat kontribusi secara langsung yang signifikan antarakepuasan kerja $\left(X_{3}\right)$ terhadap kinerja guru SMP (Y) di Kecamatan Gerokgak.

Kesebelas, berdasarkan analisis data yang telah dilakukan, secara normatif ditemukan bahwa terdapat kontribusi secara langsung yang signifikan antara kepemimpinan pelayanan kepala sekolah $\left(\mathrm{X}_{2}\right)$ terhadap kinerja guru SMP $(\mathrm{Y})$ di Kecamatan Gerokgak melalui persamaan garis regresi $\hat{y}=120,310+0,720 X_{2}$ dengan Freg $=68,638$ dengan kontribusi sebesar $33,5 \%$ adalah signifikan dan linier. Karena Freg > Ftabel. Berdasarkan analisis dengan komputer korelasi antara kepemimpinan pelayanan kepala sekolah $\left(\mathrm{X}_{2}\right)$ dengan kinerja guru SMP $(Y)$ di Kecamatan Gerokgak diperoleh $r_{\text {hitung }}=0,579$. Ini berarti $r_{\text {hitung }}=0,579$ signifikan pada $\alpha=0,05\left(r_{\text {tabel }}=0,254\right)$. Temuan ini mengindikasikan bahwa terdapat kontribusi secara langsung yang signifikan antarakepemimpinan pelayanan kepala sekolah $\left(\mathrm{X}_{2}\right)$ terhadap kinerja guru SMP (Y) di Kecamatan Gerokgak.

Ke dua belas, berdasarkan analisis data yang telah dilakukan, secara normatif ditemukan bahwa terdapat kontribusi secara langsung yang signifikan antara implementasi manajemen sekolah berbasis nilai-nilai kearifan lokal Tri Hita Karana $\left(\mathrm{X}_{1}\right)$ terhadap kinerja guru SMP $(\mathrm{Y})$ di Kecamatan Gerokgak melalui persamaan garis regresi $\hat{y}=7,432+1,524 X_{1}$ dengan Freg $=$ 280,671 dengan kontribusi sebesar $67,4 \%$ adalah signifikan dan linier. Karena Freg $>$ Ftabel. Berdasarkan analisis dengan komputer korelasi antara implementasi manajemen sekolah berbasis nilai-nilai kearifan lokal Tri Hita Karana $\left(\mathrm{X}_{1}\right)$ dengan kinerja guru SMP $(\mathrm{Y})$ di Kecamatan Gerokgak diperoleh $r_{\text {hitung }}=0,821$. Ini berarti $r_{\text {hitung }}=0,821$ signifikan pada $\alpha=0,05$ $\left(r_{\text {tabel }}=0,254\right)$. Temuan ini mengindikasikan bahwa terdapat kontribusi secara langsung yang signifikan antaraimplementasi manajemen sekolah berbasis nilai-nilai kearifan lokal Tri Hita Karana $\left(\mathrm{X}_{1}\right)$ terhadap kinerja guru SMP $(\mathrm{Y})$ di Kecamatan Gerokgak.

Ke tiga belas, berdasarkan analisis yang telah dilakukan, ditemukan bahwa terdapat korelasi yang signifikan secara bersama-sama antara manajemen sekolah berbasis nilai-nilai kearifan lokal Tri Hita Karana kepala sekolah, kepemimpinan pelayanan kepala sekolah, kepuasan kerja, dan komitmen organisasional terhadap kinerja guru SMP melalui persamaan garis regresi $\hat{y}=74,868+0,914 \cdot X_{1}+0,250 \cdot X_{2}+0,490 \cdot X_{3}+0,260 \cdot X_{4}$ dengan Freg $=176,247$ $(p<0,05)$. Ini berarti terdapat hubungan secara bersama-sama antara manajemen sekolah berbasis nilai-nilai kearifan lokal Tri Hita Karana, kepemimpinan pelayanan kepala sekolah, kepuasan kerja, dan komitmen organisasional terhadap kinerja guru SMP di Kecamatan Gerokgak. Hal ini mengindikasikan bahwa makin baik manajemen sekolah berbasis nilai-nilai kearifan lokal Tri Hita Karana, kepemimpinan pelayanan kepala sekolah, kepuasan kerja, dan komitmen organisasional makin baik pula kinerja guru SMP tersebut.

Tri Hita Karana dapat digunakan sebagai penguat dan pemupuk tumbuhnya pendidikan yang mengakar kepada kearifan lokal dengan perspektif global untuk pembangunan pendidikan berkelanjutan. Komitmen ditunjukkan dalam sikap penerimaan, keyakinan yang kuat terhadap nilai-nilai dan tujuan sebuah organisasi, begitu juga adanya dorongan yang kuat untuk mempertahankan keanggotaan dalam organisasi demi tercapainya tujuan organisasi atau dengan kata lain komitmen organisasional merupakan loyalitas seorang guru pada suatu pekerjaan atau organisasinya. Komitmen guru terhadap lembaga sekolah sebagai organisasi pada dasarnya merupakan suatu kondisi yang dirasakan oleh guru yang dapat menimbulkan perilaku positif yang kuat terhadap organisasi kerja yang dimilikinya.

Selain faktor kompetensi dan komitmen organisasional untuk meningkatkan kepuasan kerja guru, ada pula faktor lain yang mempengaruhi kepuasan kerja guru yaitu manajemen 
sekolah, pelayanan kepala sekolah sehingga meningkatkan kinerja guru. Manajemen sekolah jauh lebih penting daripada keterampilan-keterampilan terkait atau teknik komunikasi sematamata dalam menciptakan suatu organisasi yang efektif. Selain itu, manajemen sekolah yang kondusif merupakan prasyarat terselenggaranya proses pembelajaran yang efektif.

Kepuasan kerja yang tinggi menandakan bahwa sebuah organisasi sekolah telah dikelola dengan baik dan manajemen yang efektif. Kepuasan kerja yang tinggi menunjukkan kesesuaian antara harapan guru dengan imbalan yang disediakan oleh organisasi. Faktor yang mempengaruhi kepuasan kerja para guru agar berkinerja baik adalah kepemimpinan pelayanan kepala sekolah. Pengaruh kepemimpinan pelayanan Kepala Sekolah amatlah penting dalam menentukan keberhasilan sebuah organisasi. Hal ini dikarenakan kepemimpinan pelayanan Kepala Sekolah dapat membantu para guru memahami, memilih, dan merumuskan tujuan pendidikan yang akan dicapai, menggerakkan para guru, para karyawan, para siswa, dan anggota masyarakat untuk mensukseskan program-program pendidikan di sekolah dan menciptakan sekolah sebagai lingkungan kerja yang harmonis, sehat dinamis, nyaman sehingga segenap anggota dapat bekerja dengan penuh produktivitas dan memperoleh kepuasan kerja yang tinggi. Berdasarkan fenomena tersebut tampak ada hubungan antara kepuasan kerja guru dengan kepemimpinan pelayanan kepala sekolah.

Kekuatan hubungan keempat variabel bebas dengan kinerja guru SMP di Kecamatan Gerokgak secara berurutan adalah: manajemen sekolah berbasis nilai-nilai kearifan lokal Tri Hita Karana, kepemimpinan pelayanan kepala sekolah, kepuasan kerja, dan komitmen organisasional mempunyai kontribusi terhadap kinerja guru SMP.

\section{PENUTUP}

Berdasarkan hasil penelitian dan pembahasan yang telah dilakukan, maka dapat ditarik kesimpulan sebagai berikut.

(1) terdapat kontribusi secara langsung yang signifikan antara Implementasi Manajemen Sekolah Berbasis Nilai-nilai Kearifan Lokal Tri Hita Karana $\left(X_{1}\right)$ terhadap kepuasan kerja $\left(X_{3}\right)$ guru SMP di Kecamatan Gerokgak dengan koefisien korelasi sebesar 0,664.

(2) terdapat kontribusi secara langsung yang signifikan antara Implementasi Manajemen Sekolah Berbasis Nilai-nilai Kearifan Lokal Tri Hita Karana $\left(\mathrm{X}_{1}\right)$ dengan komitmen organisasional $\left(\mathrm{X}_{4}\right)$ guru SMP di Kecamatan Gerokgak dengan koefisien korelasi sebesar 0,523 .

(3) tidak terdapat kontribusi secara langsung yang signifikan antara Implementasi Manajemen Sekolah Berbasis Nilai-nilai Kearifan Lokal Tri Hita Karana $\left(X_{1}\right)$ melalui komitmen organisasional $\left(\mathrm{X}_{4}\right)$ terhadap kinerja guru $(\mathrm{Y})$ guru SMP di Kecamatan Gerokgak. Nilai pengaruh langsung sebesar 0,492 dan pengaruh tidak langsung sebesar 0,126 yang berarti bahwa nilai pengaruh langsung lebih besar dibandingkan dengan nilai pengaruh tidak langsung, hasil ini menunjukkan bahwa secara tidak langsung $X_{1}$ melalui $X_{4}$ mempunyai pengaruh yang tidak signifikan terhadap $\mathrm{Y}$.

(4) terdapat kontribusi secara langsung yang signifikan antara implementasi manajemen sekolah berbasis nilai-nilai kearifan lokal Tri Hita Karana $\left(X_{1}\right)$ dengan kepemimpinan pelayanan kepala sekolah $\left(\mathrm{X}_{2}\right)$ guru SMP di Kecamatan Gerokgak dengan koefisien korelasi sebesar $0,347$.

(5) terdapat kontribusi secara langsung yang signifikan antara kepemimpinan pelayanan kepala sekolah $\left(\mathrm{X}_{2}\right)$ dengan kepuasan kerja $\left(\mathrm{X}_{3}\right)$ guru SMP di Kecamatan Gerokgak dengan koefisien korelasi sebesar 0,495.

(6) terdapat kontribusi secara langsung yang signifikan antara kepemimpinan pelayanan kepala sekolah $\left(\mathrm{X}_{2}\right)$ dengan komitmen organisasional $\left(\mathrm{X}_{4}\right)$ guru SMP di Kecamatan Gerokgak dengan koefisien korelasi sebesar 0,463.

(7) tidak terdapat kontribusi secara langsung yang signifikan antara kepemimpinan pelayanan kepala sekolah $\left(\mathrm{X}_{2}\right)$ melalui kepuasan kerja $\left(\mathrm{X}_{3}\right)$ terhadap kinerja guru $(\mathrm{Y}) \mathrm{SMP}$ di Kecamatan Gerokgak. Nilai pengaruh langsung sebesar 0,201 dan pengaruh tidak langsung sebesar 0,059 yang berarti bahwa nilai pengaruh langsung lebih besar dibandingkan dengan 
nilai pengaruh tidak langsung, hasil ini menunjukkan bahwa secara tidak langsung $X_{2}$ melalui $\mathrm{X}_{3}$ mempunyai pengaruh yang tidak signifikan terhadap $\mathrm{Y}$.

(8) tidak terdapat kontribusi secara langsung yang signifikan antara kepemimpinan pelayanan kepala sekolah $\left(\mathrm{X}_{2}\right)$ melalui komitmen organisasional $\left(\mathrm{X}_{4}\right)$ terhadap kinerja guru $(\mathrm{Y})$ SMP di Kecamatan Gerokgak. Nilai pengaruh langsung sebesar 0,201 dan pengaruh tidak langsung sebesar 0,066 yang berarti bahwa nilai pengaruh langsung lebih besar dibandingkan dengan nilai pengaruh tidak langsung, hasil ini menunjukkan bahwa secara tidak langsung $X_{2}$ melalui $\mathrm{X}_{4}$ mempunyai pengaruh yang tidak signifikan terhadap $\mathrm{Y}$.

(9) tidak terdapat kontribusi secara langsung yang signifikan antara Implementasi Manajemen Sekolah Berbasis Nilai-nilai Kearifan Lokal Tri Hita Karana $\left(X_{1}\right)$ melalui kepuasan kerja $\left(\mathrm{X}_{3}\right)$ terhadap kinerja guru $(\mathrm{Y})$ SMP di Kecamatan Gerokgak. Nilai pengaruh langsung sebesar 0,492 dan pengaruh tidak langsung sebesar 0,125 yang berarti bahwa nilai pengaruh langsung lebih besar dibandingkan dengan nilai pengaruh tidak langsung, hasil ini menunjukkan bahwa secara tidak langsung $X_{1}$ melalui $X_{3}$ mempunyai pengaruh yang tidak signifikan terhadap $\mathrm{Y}$.

(10) terdapat kontribusi secara langsung yang signifikan antara kepuasan kerja $\left(X_{3}\right)$ terhadap kinerja guru (Y) SMP di Kecamatan Gerokgak dengan koefisien korelasi sebesar 0,783 .

(11) terdapat kontribusi secara langsung yang signifikan antara kepemimpinan pelayanan kepala sekolah $\left(\mathrm{X}_{2}\right)$ terhadap kinerja guru (Y) SMP di Kecamatan Gerokgak dengan koefisien korelasi sebesar 0,579.

(12) terdapat kontribusi secara langsung yang signifikan antara implementasi manajemen sekolah berbasis nilai-nilai kearifan lokal Tri Hita Karana $\left(\mathrm{X}_{1}\right)$ terhadap kinerja guru (Y) SMP di Kecamatan Gerokgak dengan koefisien korelasi sebesar 0,821.

(13) secara bersama-sama, ada kontribusi yang signifikan antara manajemen sekolah berbasis nilai-nilai kearifan lokal Tri Hita Karana, kepemimpinan pelayanan kepala sekolah, kepuasan kerja, dan komitmen organisasional terhadap kinerja guru SMP di Kecamatan Gerokgak dengan koefisien korelasi ganda sebesar 0,917 dan kontribusinya sebesar $84,1 \%$ terhadap kinerja guru SMP di Kecamatan Gerokgak.

Berdasarkan hasil dan kesimpulan dari penelitian ini, dapat diajukan beberapa saran sebagai berikut.

Guru hendaknya mampu untuk meningkatkan kepuasan kerja dan komitmen organisasional sehingga kinerja guru dapat ditingkatkan. Hal ini bertujuan agar proses pembelajaran yang ada di sekolah dapat berjalan secara optimal, sehingga tujuan pembelajaran yang ingin dicapai dapat tercapai secara maksimal.

Kepala sekolah hendaknya mampu untuk meningkatkan manajemen sekolah berbasis nilai-nilai kearifan lokal Tri Hita Karananya dan kepemimpinan pelayanannya sehingga kepala sekolah akan menjadi panutan bagi guru dan staf yang ada di sekolah. Selain itu kepala sekolah hendaknya juga mampu untuk mengayomi seluruh bawahannya sehingga kegiatankegiatan di sekolah dapat berjalan dengan optimal.

Peneliti lain diharapkan mampu mengembangkan variabel lain dalam usaha meningkatkan kinerja guru, sehingga dapat memberikan kontribusi pengetahuan.

\section{DAFTAR RUJUKAN}

Agung, Anak Agung Gede. 2014. Metodologi Penelitian Pendidikan. Malang: Aditya Media Publishing.

Agung, Anak Agung Gede. 2016. Statistika Dasar untuk Pendidikan. Yogyakarta; Depublish. 
Ardhana, W. 1987.Bacaan Pilihan dalam Metode Penelitian Pendidikan. Jakarta: Proyek Pengembangan Lembaga Pendidikan Tenaga Kependidikan Direktorat Jenderal Pendidikan Tinggi Departemen Pendidikan dan Kebudayaan.

Arikunto, Suharsimi. 1995. Manajemen Penelitian. Jakarta: Rineka Cipta.

Arikunto, Suharsimi. 1997. Prosedur Penelitian Suatu Pendekatan Praktek. Jakarta: Rineka Cipta.

Asf, Jasmani dan Syaiful Mustofa. 2013. Supervisi Pendidikan. Yogjakarta: ArRuzz Media.

Depdiknas. 2006. Kurikulum Tingkat Satuan Pendidikan (KTSP). Jakarta: Departemen Pendidikan Nasional.

Hamzah, B. Uno.2007. Teori Motivasi dan Pengukurannya. Jakarta: Bumi Aksana.

Puger, I Gusti Ngurah. 2004. Belajar Kooperatif. Diktat Perkuliahan Mahasiswa Unipas.

Rohiat.2010. Manajemen Sekolah Teori Dasar dan Praktek. Bandung: PT. Alfabeta.

Sugiyono. 2016. Metode Penelitian Kuantitatif, Kualitatif dan R\&D. Bandung: PT Alfabet.

Wallen, Norman E. 1993. Educational Research A Guide to The Process. California: Wadsworth Publishing Company. 